\title{
ANALISIS EFEKTIVITAS KEGIATAN PRAKTIKUM SEBAGAI UPAYA PENINGKATAN HASIL BELAJAR MAHASISWA
}

\author{
Dwi Wahyudiati \\ IAIN Mataram, Mataram, Indonesia \\ dwiwahyudiati2015@gmail.com
}

\begin{abstract}
Abstrak
Fokus penelitian ini adalah untuk mengethaui bagaimanakah perencanaan, pelaksanaan, dan faktor-faktor apa saja yang mempengaruhi kualitas pelaksanaan kegiatan praktikum Kimia Dasar Di Jurusan Pendidikan IPA Biologi Tahun Akademik 2015/2016 sebagai dasar untuk meningkatkan hasil belajar mahasiswa. Pendekatan penelitian yang digunakan adalah pendekatan penelitian kualitatif dengan jenis penelitian deskriptif kuantitaif dengan sumber data terdiri dari mahasiswa, dosen pengampu mata kuliah, laboran, dan coass parktikum mata kuliah Kimia Dasar.Berdasarkan hasil penelitian diperoleh data sebagai berikut: (1) Pada aspek persiapan pelaksanaan (perencanaan), secara umum subyek penelitian melakukan persiapan praktikum dengan cukup baik, dengan kelemahan kurangnya pemahaman mahasiswa terhadap materi yang dipraktikumkan, mempersiapkan alat dan bahan, dan konsultasi dengan coass, (2) Pada aspek pelaksanaan praktikum dilakukan dalam 3 tahapan/proses yaitu, tahap persiapan, pelaksanaan, dan tahap akhir yang dalam pelaksanaannya berjalan dengan lancar tetapi masih kurang lengkapnya alat dan bahan, kesulitan dalam menyusun laporan praktikum, jadwal kuliah yang kurang sinkron dengan jadwal praktikum, kurangnya bimbingan dari dosen pengampu mata kuliah, penjelasan coass kurang dipahami. Adapun usaha yang dilakukan dalam meningkatkan kualitas pelaksanaan praktikum menunjukkan subyek penelitian melakukan upaya yang cukup intensif secara kuantitasdan selalu melakukan kegiatan evaluasi baik oleh praktikan, coass, laboran, dan dosen pengampu mata kuliah akan tetapi masih perlu dioptimalkan masing-masing peranan, sedangkan berkaitan dengan faktor yang mempengaruhi kualitas pelaksanaan praktikum Kimia Dasar menunjukkan bahwa motivasi mahasiswa mengikuti praktikum sangat tinggi, peran dosen, coass, dan laboran masih perlu ditingkatkan, serta ketersediaan sarana dan prasarana yang masih terbatas.
\end{abstract}

Kata Kunci: Analisis Kegiatan, Praktikum, Laboratorium, Peningkatan Hasil Belajar

\footnotetext{
Abstract

The current research intends to clarify the lab activities program of Basic Chemistry course (including its planning and implementation) at Science Education Department of IAIN Mataram and the factors affecting the quality of the program in order to maximize students' learning achievement. It is a qualitative research where that data are obtained from students, lecturers, and laboratory assistances. The research found the following remarks: 1) the planning process shows that students have weaknesses on their understanding of the topic being practiced, their capability on using the tools and stuff used in the practices, and on the quantity of consultation to laboratory assistances; 2) During the implementation process, there some blind spots such as inadequate equipment to do lab activities, students' difficulties in compiling report,
} 
unsynchronized schedule of lab activities, and inadequate explanation and consultation to supporting lecturers and laboratory assistances. To anticipate the problems above, an intensive evaluation is held together with students, laboratory assistances, and supporting lecturers to optimize their roles. The factors contributing to the quality of the lab activity are student motivation, the lecturers and laboratory assistances contributions, and the lab equipment.

Keywords: Activity Analysis, Lab Activity, Laboratory, Enhance Learning Outcome

\section{PENDAHULUAN}

Ilmu Kimia yang merupakan salah satu bidang dari Ilmu Pengetahuan Alam (IPA) mempunyai ciri-ciri khusus yang perlu ditangani secara khusus.Salah satu ciri dari IPA adalah adanya kerjasama antara eksperimen dan teori. Teori dalam IPA tidak lain adalah pemodelan matematis terhadap berbagai prinsip dasar yang kebenarannya harus diuji dengan eksperimen. Pada dasarnya eksperimen, selain merupakan suatu proses induktif dalam menanamkan prinsip dasar yang baru, juga merupakan suatu proses deduktif bagi pengujian teori baru. Kiranya tidak dapat disangsikan bahwa praktikum yang merupakan salah satu kegiatan laboratorium sangat berperanan dalam menunjang keberhasilan proses belajar mengajar IPA. Dengan kegiatan praktikum, mahasiswa akan dapat mempelajari IPA melalui pengamatan langsung terhadap gejala-gejala maupun proses-proses IPA, dapat melatih keterampilan berpikir ilmiah, dapat menanamkan dan mengembangkan sikap ilmiah, dapat menemukan dan memecahkan berbagai masalah baru melalui metode ilmiah (Amien, 1987; Hendro dan Jenny, 1993).

Demikian juga dengan mata kuliah Kimia Dasar merupakan kelompok IPA yang pada hakikatnya menkankan pada aspek produk, sikap, kognitif, dan psikomotorik yang pada penerapannya beracuan pada prinsip inquiri ilmiah (scientific inquiri) atau penemuan ilmiah. Oleh karena itu, pada proses pembelajarannya di kelas memerlukan metode yang tepat untuk merealisasikan prinsip penemuan ilmiah tersebut. Di mana, metode yang paling tepat untuk menerapkan pendekatan tersebut adalah dengan 
Wahyudiati, D. (2016). ANALISIS EFEKTIVITAS KEGIATAN PRAKTIKUM SEBAGAI UPAYA PENINGKATAN HASIL BELAJAR MAHASISWA. JURNAL TATSQIF, 14(2).

Retrieved from http://ejurnal.iainmataram.ac.id/index.php/tatsqif/article/view/1024

menerapkan metode eksperimen. Eksperimen merupakan cara penyajian materi pelajaran dengan menggunakan percobaan atau praktikum.

Pada pelaksanaan proses pembelajaran di kelas, pelaksanaan kegiatan praktikum mempunyai peranan yang sangat krusial untuk mendukung kualitas hasil dan proses pembelajaran karena kegiatan praktikum akan lebih efektif untuk meningkatkan keahlian siswa dalam pengamatan dan meningkatkan keterampilan/aspek psikomotorik serta sebagai sarana berlatih dalam menggunakan atupun memanfaatkan alat dan bahan yang ada di laboratorium. Selain itu, dengan kegiatan praktikum dapat mengembangkan rasa ingin tahu siswa/mahasiswa, akan menumbuhkan keaktifan, sikap kerjasama, ketelitian, toleran, serta menumbuhkan kejujuran ilmiah pada diri siswa/mahasiswa.

Demikian halnya dengan mata kuliah Kimia Dasar, di Fakultas Ilmu Tarbiyah dan Keguruan IAIN Mataram merupakan mata kuliah kompetensi yang harus ditempuh pada semester awal yang tidak hanya ditempuh oleh mahasiswa pada Jurusan Kimia saja tapi pada semua jurusan MIPA seperti pada Jurusan Biologi, Matematika, dan Fisika. Mata kuliah Kimia Dasar ini terdiri dari 3 SKS yang terintegrasi dengan praktikum.Untuk perkuliahan bernilai 2 SKS dan untuk praktikum bernilai 1 SKS.

Pada praktikum Kimia Dasar mahasiswa diharapkan dapat dibekali penguasaan psikomotorik yang didukung dengan afektif dan kognitif. Pelaksanaan praktikum dievaluasi mengikuti tata cara tertentu mulai dari responsi (evaluasi pemahaman mahasiswa terhadap apa yang akan dilakukan di laboratorium baik itu berupa teori maupun prosedur kerja praktikum), evaluasi aktifitas (keaktifan), laporan dan ujian akhir mata kuliah.

Khususnya pada mata kuliah Kimia Dasar yang diajarakan pada Jurusan Pendidikan IPA Biologi memuat materi yang disusun berdasarkan kompetensi dasar dan tujuan pembelajaran yang diharpkan dapat dicapai oleh mahasiswa. Materi-materi tersebut antara lain; Stoikiometri, Asam Basa, 
Wahyudiati, D. (2016). ANALISIS EFEKTIVITAS KEGIATAN PRAKTIKUM SEBAGAI UPAYA PENINGKATAN HASIL BELAJAR MAHASISWA. JURNAL TATSQIF, 14(2).

Retrieved from http://ejurnal.iainmataram.ac.id/index.php/tatsqif/article/view/1024

Tabel Periodik Unsur, Ikatan Kimia, Karbohidrat, Protein, Lipid, dan Enzim. Semua materi-materi tersebut telah dipelajari di SMA/MA, dengan demikian mata kuliah Kimia Dasar bukan hal yang baru bagi mahasiswa sehingga dalam pemahaman materi akan lebih mudah memahami materi-materi yang diajarkan baik dalam kegiatan perkuliahan ataupun kegiatan praktikum baik di laboratorium maupun praktikum lapangan.

Akan tetapi, berdasarkan fakta di lapangan, ditemukan bahwa antara kenyataan dan harapan masih terpaut sangat jauh karena berdasarkan data 2 tahun terakhir untuk nilai praktikum mahasiswa masih sangat jauh dari yang diharapkan, dimana 70\% nilai praktikum mahasiswa pada mata Kuliah Dasar termasuk dalam kategori tidak tuntas. Terlebih lagi pada mahasiswa semester I (Semester Ganjil) Tahun Akademik 2015/2016 diperoleh data nilai praktikum Kimia Dasar sangat rendah, di mana dari 150 orang mahasiswa yang menempuh mata kuliah Kimia Dasar hanya 22 orang mahasiswa yang memperoleh nilai tuntas dengan rentang nilai 60-70. Hal ini berarti bahwa hanya 14,7\% mahasiswa yang tuntas dan 85,3\% termasuk dalam kategori tidak tuntas (Sumber: Nilai Praktikum Semester Ganjil TA 2015/2016).Data tersebut menjadi bukti bahwa sebagian besar mahasiswa mengalami kesulitan dalam pelaksanaan kegiatan praktikum Kimia Dasar sehingga hasil belajar yang diharapkan tidak dapat tercapai sebagaimana mestinya.

Permasalahan di atas menjadi acuan peneliti di dalam mengkaji faktor-faktor penyebab sangat rendahnya nilai praktikum mahasiswa pada mata Kuliah Kimia Dasar sehingga peneliti menyimpulkan bahwa sangat urgen untuk melakukan penelitian ini dengan judul Analisis Efektivitas Kegiatan Praktikum Kimia Sebagai Upaya Peningkatan Hasil Belajar Mahasiswa dengan fokus penelitian yaitu untuk mengetahui bagaimanakah perencanaan, pelaksanaan, dan faktor-faktor yang mempengaruhi pelaksanaan praktikum Kimia Dasar di Jurusan Pendidikan IPA Biologi FITK IAIN Mataram. 


\section{METODE PENELITIAN}

\section{Pendekatan dan Jenis Penelitian}

Adapun pendekatan penelitian yang digunakan pada penelitian ini adalah pendekatan penelitian kualitatif dengan jenis penelitian deskriptif kuantitaif. Menurut Sukardi (2005:157), penelitian deskriptif kuantitatif adalah peneliti berusaha memberikan gambaran informasi mengenai status suatu gejala yang diperoleh pada saat penelitian dilakukan. Arikunto (2010:3) menyatakan dalam penelitian deskriptif tidak mengubah, menambah atau memanipulasi objek penelitian. Pada penelitian deskriptif, tidakada perlakuan yang diberikan atau dikendalikan seperti yang dapat ditemui pada penelitian eksperimen dan bertujuan untuk menjelaskan variabel atau kondisi apa yang ada dalam suatu situasi.

Untuk gambaran jelasnya bagaimana penelitian ini akan dilakukan dan output apa yang akan dihasilkan dapat dilihat pada bagan di bawah ini: 


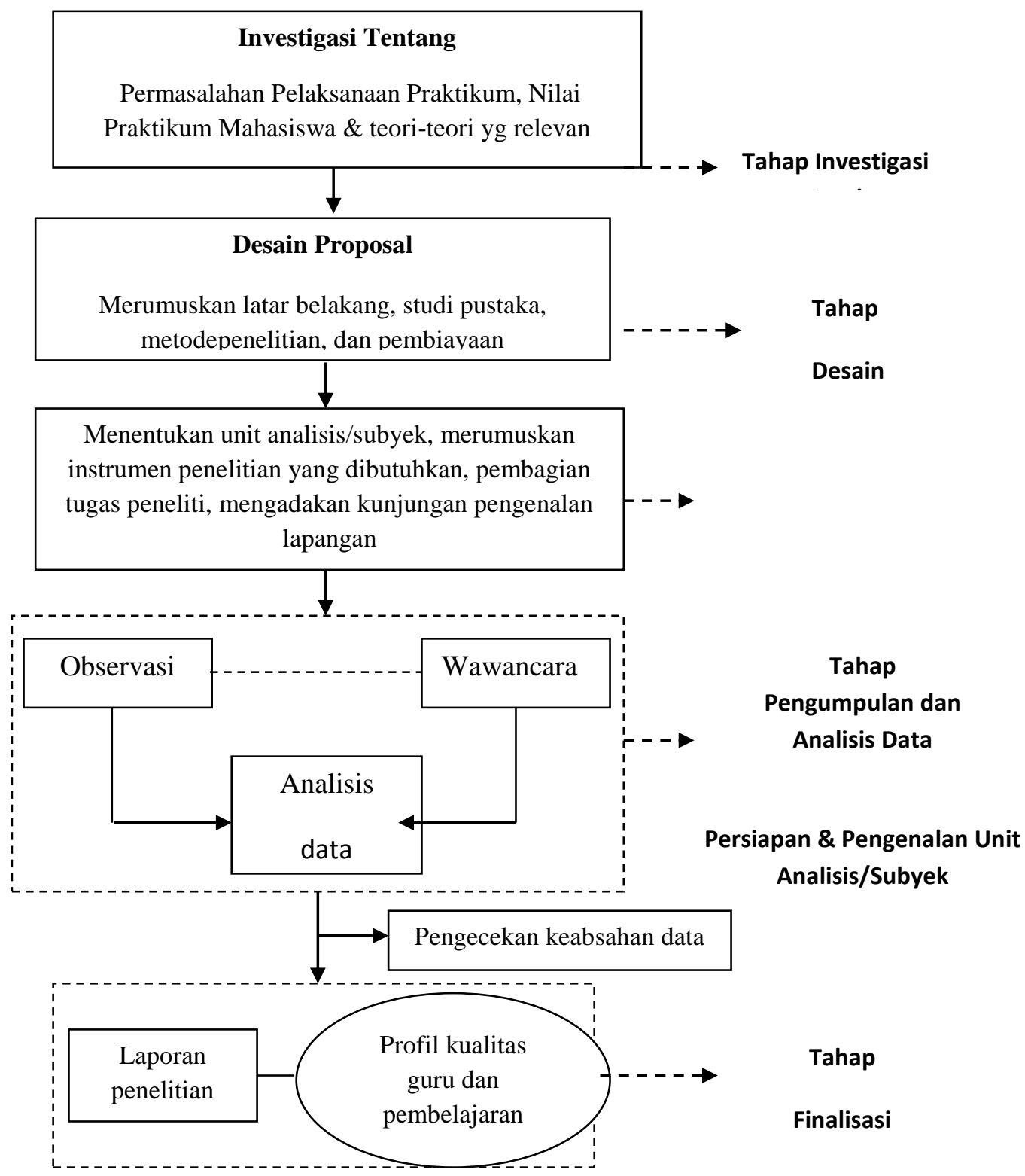

Gambar 1

Desain Penelitian

\section{Tempat dan waktu}

Tempat dan waktu penelitian dilaksanakan dari bulan AprilAgustus tahun 2016 yang bertempat di Jurusan Pendidikan IPA Biologi Fakultas Ilmu Tarbiyah dan Keguruan IAIN Mataram Tahun Akademik 2015/2016. 


\section{Sumber Data}

Data yang dikumpulkan dalam penelitian ini adalah data kualitatif yang berupa kata-kata dan tindakan.Jenis-jenis data pada penelitian kualitatif adalah kata-kata dan tindakan (Sugiono,2006) dan data kuantitatif. Data-data tersebut didapatkan dari hasil angket dan wawancara terhadap mahasiswa, dosen, laboran, dan Coass terkait dengan persiapan/perencanaan, pelaksanaan, sarana dan prasarana, serta faktor-faktor yang mempengaruhi kualitas pelaksanaan praktikum Kimia Dasar.

Adapun dalam menentukan subyek penelitian, peneliti terlebih dahulu menentukan unit analisis penelitian, yang dalam hal ini unit analisisnya adalah mahasiswa semester II Jurusan Pendidikan IPA Biologi Tahun Akademik 2015/2016. Dalam menentukan unit analisis peneliti menggunakan teknik snowball random sampling.Setelah unit analisis ditentukan peneliti menentukan subyek penelitian. Teknik yang digunkan dalam menentukan subyek penelitian adalah teknik purposive. Dengan teknik ini subyek penelitian ditentukan secara kebetulan dan bergulir pada unit analisis yang telah dipilih baik mahasiswa maupun mahasiswi. Penentuan jumlah subyek penelitian dengan teknik ini didasarkan pada ketercukupan data. Apabila data sudah dirasakan cukup atau jenuh maka penelitian dihentikan. Sebaliknya apabila data yang terkumpul masih dirasakan kurang, proses pengumpulan data terus dilakukan sampai data yang terkumpul jenuh.

\section{Teknik Pengumpulan Data}

Berdasarkan jenis penelitian, rumusan masalah dan sumber data, teknik pengumpulan data yang diganakan dalam penelitian ini adalah teknik pemberian angket dan wawancara.Penggunaan teknikteknik tersebut didasarkan pada jenis data yang diambil. 


\section{a. Teknik Wawancara}

Teknik wawancara yang digunakan adalah wawancara tak terstruktur.Wawancara tak terstruktur merupakan wawancara yang bebas dimana peneliti tidak menggunakan pedoman wawancara yang disusun secara sistimatis dan rinci. Pedoman wawancara yang dibuat hanya berisi garis-garis besar masalah yang akan diteliti. Dengan cara ini peneliti dapat menggali secara luas dan mendalam informasi-informasi yang dibutuhkan dari subyek penelitian. Wawancara dalam penelitian ini bertujuan untuk mengetahui informasi-informasi yang berkaitan dengan persiapan praktikum, pelaksanaan praktikum, dan untuk mendapatkan data yang terkait dengan faktor-faktor yang mempengaruhi kualitas pelaksanaan praktikum Kimia Dasar di Jurusan Pendidikan IPA Biologi.

\section{b. Teknik Angket}

Untuk teknik angket pada penelitian ini untuk mendukung data yang diperoleh dari hasil wawancara yang bertujuan untuk mengetahui informasi-informasi yang berkaitan dengan kualitas persiapan/perencanaan praktikum, kualitas pelaksanaan praktikum Kimia Dasar di Jurusan Pendidikan IPA Biologi FITK IAIN Mataram Tahun Akademik 2015/2016.

\section{Analisis Data}

Dalam menganalisis data, peneliti menggunakan teknik analisis data kualitatif model Miles \& Huberman. Penggunaan teknik tersebut didasarkan atas kesesuaiannya dengan jenis data yang akan dianalisis, yaitu data yang dikumpulkan dengan teknik observasi dan wawancara.

Teknik analisis data model Miles dan Huberman mencakup tiga tahapan, yaitu; reduksi data, penyajian data, dan kesimpulan atau verifikasi yang termasuk reduksi data adalah proses memilih data, 
pemokusan data, penyederhanaan data, mengabstraksi data, dan mentranskrip data. Adapun yang termasuk dalam penyajian data adalah mengorganisasi data, meringkas atau memadatkan data. Sedangkan verifikasi merupakan kegiatan untuk menarik kesimpulan dari data-data yang sudah dianalisis. Pada tahapan-tahapan inilah kegiatan analisis data dilakukan peneliti, yaitu mulai sejak data direduksi sampai data diverifikasi, bahkan menurutnya bisa dimulai sejak pengumpulan data.

Berdasarkan model analisis tersebut, maka tahapan analisis data yang dilakukan peneliti sebagai berikut; setelah data terkumpul, peneliti melakukan reduksi data.Yang dilakukan peneliti pada tahap ini adalah memilih, menyederhanakan, atau menyortir data kasar yang telah terkumpul atau tercatat dalam lembar observasi dan wawancara, sekaligus membuang data yang tidak perlu.Data tersebut kemudian dipilah-pilah dan dikelompokkan berdasarkan jenisnya. Setelah data direduksi, selanjutnya peneliti menyusun data tersebut ke dalam susunan yang sistimatis dan kemudian dianalisis dengan cara mengkonsultasikannya dengan teori-teori dan hasil penelitian terdahulu yang relevan. Setelah proses tersebut selesai dilakukan, peneliti melakukan penarikan kesimpulan terhadap hasil analisis data tersebut yang sekaligus menjawab rumusan masalah penelitian. Kegiatan ini dilakukan peneliti secara terus-menerus setiap kali pengambilan data dilakukan.

\section{Validitas Data}

Untukmenjaga tingkat kepercayaan terhadap hasil penelitian yang dilakukan, peneliti melakukan uji kredibelitas (derajat kepercayaan) dan transferabilitas (keteralihan). Sedangkan uji auditabilitas (konsistensi) tidak dilakukan karena dalam penelitian kualitatif uji auditability tidak bisa dilakukan oleh peneliti, tapi dilakukan oleh orang luar (pembimbing atau orang lain). Hal ini sesuai 
dengan pendapat yang dikemukakan Stainback yang mengatakan bahwa penelitian kualitatif lebih menekankan pada aspek validitas data, bukan reliabilitas (Moleong, 2006).

Kredibilitas berfungsi untuk meningkatkan dan menunjukkan tingkat kepercayaan terhadap data atau penemuan yang dicapai. Sedangkan keteralihan (transferabilitas) berfungsi untuk membuktikan derajat ketetapan atau apakah hasil penelitian tersebut dapat berlaku pada populasi dimana sample itu diambil atau tidak. Berkaitan dengan keteralihan (transferabilitas) pada penelitian kualitatif tidak dapat dijamin oleh peneliti, karena hal tersebut sangat tergantung pada pandangan pemakai (Sugiyono, 2006).

Berdasarkan pendapat tersebut, maka yang dilakukan oleh peneliti hanya uji kredibilitas untuk menjaga kepercayaan terhadap data atau hasil penelitian yang dilakukan. Sedangkan untuk keteralihan (transferabilitas) peneliti berupaya menyusun laporan penelitian secara rinci, jelas, sistimatis, dan dapat dipercaya, sehingga orang lain dapat memahami hasil penelitian tersebut. Dengan demikian ada kemungkinan hasil penelitian tersebut dapat diterapkan pada konteks dan situasi yang lain.

Adapun untuk menjaga tingkat kepercayaan (akuntabilitas) terhadap data dan hasil penelitian ini, peneliti melakukan upayaupaya seperti yang dikemukakan (Fraenkel, 2003).Upaya-upaya dimaksud adalah; (1) perpanjangan pengamatan atau keikutsertaan. Kegiatan ini dilakukan dengan cara melakukan obsevasi lebih dari sekali pada sumber data yang sama. Dengan demikian diharapkan data yang diperoleh bebas dari pengaruh lain dan alamiah. (2) meningkatkan ketekunan. Artinya peneliti melakukan pengumpulan data dan analisis tentatif secara hati-hati, cermat dan mendalam. (3) triangulasi. Triangulasi yang dilakukan dalam penelitian ini adalah triangulasi metode dimana metode yang digunakan adalah obsevasi 
dan wawancara.(4) pengecekan oleh informan (membercheck). Kegiatan ini dilakukan setelah analisis data dilakukan atau adanya temuan.

\section{HASIL DAN PEMBAHASAN}

Secara sempit laboratorium diartikan sebagai ruangan yang dibatasi oleh dinding yang di dalamnya terdapat alat-alat dan bahan-bahan beraneka ragam yang dapat digunakan untuk melakukan eksperimen (Subiyanto, 1998 : 79). Sudaryanto (1998: 2) mendefinisikan laboratorium sebagai salah satu sarana pendidikan IPA, sebagai tempat peserta didik berlatih dan kontak dengan objek yang dipelajari secara langsung, baik melalui pengamatan maupun percobaan.

Lebih lanjut Sudaryanto (1998: 7) menyatakan peranan dan fungsi laboratorium ada tiga, yaitu sebagai (1) sumber belajar, artinya lab digunakan untuk memecahkan masalah yang berkaitan dengan ranah kognitif, afektif, dan psikomotor atau melakukan percobaan, (2) metode pendidikan, meliputi metode pengamatan dan metode percobaan, dan (3) sarana penelitian, tempat dilakukannya berbagai penelitian sehingga terbentuk pribadi peserta didik yang bersikap ilmiah. Secara lebih umum laboratorium diartikan sebagai suatu tempat dilakukannya percobaan dan penelitian (Depdikbud, 1994 : 7). Pengertian ini bermakna lebih luas, karena tidak membatasi laboratorium sebagai suatu ruangan, artinya kebun, lapangan, ruang terbukapun dapat menjadi laboratorium.

\section{Perencanaan Pelaksanaan Praktikum Kimia Dasar di Jurusan Pendidikan IPA Biologi FITK IAIN Mataram.}

Berdasarkan hasil wawancara, yang kemudian dipadukan dengan jawaban-jawaban pada angket (1-7 Juli 2016) bahwa 100\% dari sampel melakukan persiapan sebelum melakukan kegiatan praktikum Kimia Dasar di Laboratorium yang terdiri dari; membaca literatur terkait materi yang dipraktikumkan, mempelajari prosedur kerja pada petunjuk 
praktikum atau persiapan lainnya). Berdasarkan hasil penelitian menunjukkan bahwa 83,3\% menyatakan selalu melakukan persiapan sebelum memulai kegiatan praktikum yang bertujuan untuk memudahkan melaksanakan kegiatan praktikum Kimia Dasar karena persiapan pelaksanaan praktikum merupakan tahap yang sangat penting dalam menentukan keberhasilan suatu praktikum.

Persiapan-persiapan yang dilakukan diantaranya yaitu; membaca literatur terkait materi praktikum, membaca prosedur kerja, alat bahan yang diperlukan pada pelaksanaan praktikum, mempersiapkan mental, kerjasama dengan anggota kelompok, dan persiapan untuk menjawab pertanyaan coass, respon awal, memahami rumus-rumus untuk penyelesaian anlisis data,dll. Sedangkan 16,67\% menyatakan kadangkadang melakukan persiapan.

Menurut Sund dan Trowbridge, (dalam Sumaji, 2003: 43) kerja laboratorium atau praktikum meliputi 1) merencanakan eksperimen dan menyusun hipotesis-hipotesis, 2) merakit peralatan, 3) menyusun bahan dan peralatan, 4) melakukan pengamatan terhadap gejala-gejala alamiah, 5) melakukan pengamtan terhadap suatu proses, 6) mengumpulkan dan mencatat data, 7) melakukan modifikasi peralatan, 8) melakukan pembacaan pada alat pengukur ,9) kalibrasi peralatan, 10) menggambar bahan dan grafik, 11) menganalisis data, 12) menarik kesimpulan dari data, 13) membuat laporan eksperimen, 14) memberi penjelasan tentang eksperimen yang dilakukan, 15) mengidentifikasi permasalahan untuk studi lanjutan, 16) melepas, membersihkan, menyimpan, dan memperbaiki peralatan.

Adapun persiapan-persiapan yang dilakukan oleh Dosen pengampu mata kuliah Kimia Dasar adalah; menyiapkan atau menyusun modul/buku petunjuk praktikum Kimia Dasar yang disesuaikan dengan konten materi perkuliahan, koordinasi dengan laboran terkait dengan acara-acara yang akan dipraktikumkan dan juga mengkoordinasikan 
terkait dengan alat dan bahan yang dibutuhkan pada saat pelaksanaan praktikum. Selain itu, kegiatan yang sangat mendukung kelancaran proses praktikum adalah dengan melakukan kegiatan pembekalan dengan para Coass praktikum Kimia Dasar yang bertujuan untuk memberikan penjelasan dan pemahaman lebih terkait dengan acara yang akan dipraktikumkan sehingga para Coass tersebut tidak mengalami kendala dalam membimbing praktikan dalam pelaksanaan praktikum Kimia Dasar.

Selain itu, dalam mempersiapkan pelaksanaan praktikum di laboratorium, maka hal-hal yang perlu dipersiapkan antara lain alat-alat dan bahan-bahan kimia, perlengkapan praktikum, buku petunjuk praktikum, jadwal pelaksanaan, dan kesiapan dosen, praktikan, Coass, dan laboran. Hal lain yang perlu diperhatikan dalam mendesain suatu kegiatan praktikum adalah tujuan praktikum yang diinginkan dan penentuan teori yang sesuai dengan mata praktikum, serta bagaimana menentukan dan memilih alat dan bahan kimia yang sesuai dan tepat dalam praktikum.

Pada proses mempersiapkan Pelaksanaan Praktikum Kimia Dasar berdasarkan hasil penelitian diperoleh data bahwa 61,9\% responden menyatakan mengalami kesulitan dalam mempersiapkan pelaksanaan praktikum mata kuliah Kimia Dasar, 2,38\% menyatakan kadang-kadang mengalami kesulitan, sedangkan 35,71\% menyatakan tidak kesulitan di dalam melaksanakan persiapan pelaksanaan praktikum Kimia Dasar di Jurusan Pendidikan IPA Biologi IAIN Mataram.

Adapun kesulitan yang dihadapai oleh mahasiswa diantaranya; kesulitan dalam memperoleh literatur yang sesuai dengan yang dipraktikumkan, pemahaman materi (pembuatan larutan, satuan-satuan konsentrasi, kesulitan konsultasi dengan Coass, prosedur kerja yang sulit, hasil praktikum berbeda dengan materi), mempersiapkan alat dan bahan, membuat laporan praktikum, dan yang paling kesulitan yaitu pada saat 
konsultasi dengan coass terkait dengan waktu dan kesibukan masingmasing antara praktikan dengan Coass.

Pada tahap persiapan pelaksanaan praktikum Kimia Dasar yang menjadi kendala utama yang dihadapi oleh mahasiswa adalah kurangnya pemahaman materi terutama terkait dengan materi yang dipraktikumkan. Acara yang dipraktikumkan antara lain; pembuatan larutan, satuan-satuan konsentrasi seperti konsep mol, fraksi mol, kadar zat, dan penentuan persentase larutan. Selain itu, yang menjadi banyak keluhan dari praktikan adalah mengalami kesulitan pada saat melakukan konsultasi dengan Coass baik pada konsultasi acara-acara praktikum maupun pada saat pembuatan laporan praktikum dengan adanya perbedaan persepsi dengan Coass yang satu dengan yang lainnya, dan juga kesulitan dalam menyesuaikan waktu antara Coass dengan para praktikan. Kondisi tersebut harus mendapat perhatian khusus oleh laboran, dosen pengampu mata kuliah maupun oleh pihak Jurusan.

Pemahaman Mahasiswa Terhadap Petunjuk Praktikum Kimia Dasar. Sebelum pelaksanaan praktikum beberapa hal yang paling menentukan keberhasilan praktikum yaitu terutama petunjuk Praktikum yang didalamnya memuat materi praktikum, prosedur kerja, dan latihanlatihan soal. Berdasarkan ,hasil penelitian diperoleh data bahwa 88,1\% responden menyatakan sebelum pelaksanaan praktikum dilaksanakan praktikan dibagikan buku petunjuk praktikum Kimia Dasar, dan 11,9\% menyatakan kadang-kadang dibagikan.

Selain itu, terkait dengan pemahaman praktikan terhadap isi buku petunjuk praktikum Kimia Dasar menyatakan 64,3\% responden menyatakan mudah memahami isi petunjuk praktikum, dan 35,7\% responden menyatakan kurang dapat memahami isi petunjuk praktikum Kimia Dasar. Alasan praktikan menyatakan mudah memahami petunjuk praktikum diantaranya; isi petunjuk praktikum simple, kalau untuk Coass alasannya sudah dipraktikkan sebelumnya,bahan yang dugunakan mudah 
dipahami, materi sesuai dengan yang diajarkan Coass, lengkap dan mudah dimengerti, sudah ada prosedur kerja, bahasanya mudah dipahami, kalimat-kalimatnya menarik untuk di baca. Alasan responden yang menyatakan kurang memahami adalah; kata-kata yang baku, kurang lengkap dan rinci, perbedaan rumus dengan waktu pembekalan sehingga menimbulkan perbedaan persepsi, dan terlalu banyak bahasa latinnya.

Pengarahan Sebelum Mulai Praktikum. Adanya pengarahan sebelum mulai praktikum sangat mendukung pelaksanaan praktikum karena sebagai dasar dan penahaman awal sebelum memulai kegiatan praktikum. Berdasarkan data yang diperoleh menunjukkan 85,7\% menyatakan sebelum mulai praktikum selalu diberikan pengarahan terlebih dahulu, dan 14,3\% menyatakan kadang-kadang diberikan pengarahan sebelum mulai praktikum. Selain itu, pendapat responden terkait dengan pengarahan yang dilakukan dapat mendukung pelaksanaan praktikum, ada yang berpendapat kurang dengan alas an pengarahan dari dosen pengampu yang masih kurang,waktu yang terbatas, simulasi perlu dilakukan, dan pengarahan dari Coass dan Dosen perlu dioptimalkan. Alasan responden yang menyatakan sangat mendukung antara lain; selalu diberikan arahan oleh Coass sebelum mulai praktikum, diarahkan langsung oleh dosen pengampu mata kuliah, diberikan kesempatan bertanya dan diskusi, mengarahkan prosedur kerja sehingga sangat mendukung kelancaran pelaksanaan praktikum Kimia Dasar.

2. Pelaksanaan/Tahapan-Tahapan Pelaksanaan Praktikum Kimia Dasar di Jurusan Pendidikan IPA Biologi FITK IAIN Mataram

Pelaksanaan merupakan salah satu fungsi manajemen yang sangat penting, karena tanpa pelaksanaan terhadap apa yang telah direncanakan dan diorganisasikan tidak akan pernah menjadi kenyataan. Kegiatan laboratorium kimia / IPA diartikan sebagai kegiatan yang 
berkaitan dengan pengamatan atau percobaan yang menunjang kegiatan belajar-mengajar kimia / IPA. Untuk melaksanakan kegiatan laboratorium kimia / IPA perlu perencanaan secara sistematis agar dicapai tujuan pembelajaran secara optimal (Depdikbud, 1999 : 13).

Adapun langkah-langkah pelaksanaan kegiatan laboratorium kimia / IPA adalah :

a. Setiap dosen pada awal semester / tahun pelajaran baru sebaiknya menyusun program semester / tahunan sesuai kegiatan lab yang ditandatangani Ketua Jurusan. Tujuan penyusunan program ini adalah mengidentifikasi kebutuhan alat / bahan yang dibutuhkan untuk kegiatan praktikum selama satu semester / tahunan dan menyusun jadwal bagi penanggung jawab teknis untuk setiap mata kuliah agar tidak terjadi tumbukan dalam pemakaian lab. Selain itu berguna untuk keperluan supervisi / pengawasan bagi Ketua Jurusan.

b. Setiap akan melaksanakan praktikum, setiap dosen sebaiknya mengisi format permintaan / peminjaman alat / bahan yang kemudian diserahkan kepada laboran minimal seminggu sebelum pelaksanaan, sehingga laboran secara dini dapat mempersiapkan dan mengecek ada tidaknya alat / bahan yang dibutuhkan.

c. Setelah kegiatan lab selesai sebaiknya dosen mengisi buku harian untuk mengetahui kejadian-kejadian selama kegiatan lab serta untuk keperluan supervisi.

d. Alat / bahan yang telah selesai digunakan segera dibersihkan dan disimpan kembali di tempat semula.

Pada pelaksanaan suatu praktikum, secara umum dilakukan dalam beberapa tahapan/proses yang harus dilakukan antara lain, tahapan persiapan, pelaksanaan, dan tahap akhir.Pada aspek ini yang menjadi fokus utama penelitian yang dilakukan adalah terkait dengan partisipasi Dosen pengampu mata kuliah, partisipasi Coass, partisipasi Laboran, dan partsisipasi praktikan. Selain itu juga yang menjadi 
fokus pada penelitian ini adalah kesesuaian antara materi praktikum dengan materi perkuliahan, kesulitan yang dihadapai selama pelaksanaan praktikum, dan aspek-aspek yang lainnya.

Berdasarkan hasil penelitian diperoleh data bahwa 80,95\% responden menyatakan setiap pelaksanaan praktikum Kimia Dasar terlebih dahulu dibimbing untuk memahami prosedur kerja yang akan dilaksanakan, 16,7\% menyatakan kadang-kadang, dan 2,38\% menyatakan tidak dilakukan bimbingan dalam memahami prosedur kerja. Adapun bentuk bimbingan yang dilakukan antara lain; pemahaman materi yang akan dipraktikumkan dengan metode bimbingan yang dilakukan berupa pengarahan yang dilakukan oleh laboran, pengarahan yang dilakukan oleh Coass, dan untuk mengetahui pemahaman awal dari praktikan dengan cara pemberian pretest terlebih dahulu sebelum mulai praktikum yang juga bertujuan untuk memotivasi praktikan dalam mempersiapkan diri sebelum mulai praktikum.

Selanjutnya pengarahan atau bentuk bimbingan yang dilakukan adalah dengan pengenalan dan penjelasan terkait dengan penggunaan alat dan bahan yang akan digunakan. Penjelasan ini sangat penting dilakukan karena terkait dengan sifat alat dan bahan-bahan kimia yang akan digunakan oleh praktikan merupakan bahan-bahan kimia yang memerlukan penanganan khusus sehingga tidak membahayakan para praktikan, baik dalam penggunaan alat dan bahan maupun dalam tahap penyimpanan alat dan bahan laboratorium tersebut.

Terkait dengan metode yang diterapkan pada saat pelaksanaan praktikum berdasarkan hasil penelitian menunjukkan bahwa sebagain besar mahasiswa menyatakan metode yang diterapkan pada pelaksanaan praktikum Kimia Dasar sudah sesuai dan sangat tepat karena sudah memberikan kemudahan dalam memahami materi dan metodenya sesuai dengan tingkat kemampuan 
praktikan. Adapun yang menjawab kurang tepat disebabkan karena pada saat bimbingan terkesan Coass belum mempersiapkan diri sehingga terkesan kurang memahami materi yang akan dipraktikumkan.

Pada pelaksanaan praktikum kimia dasar terdiri dari 3 tahapan yaitu; (1) tahap persiapan yang meliputi kegiatan respon awal dengan cara memberikan pertanyaan kepada responden terkait dengan materi praktikum sehingga responden harus mempersiapkan diri sebelum mulai melaksanakan praktikum, dan mempersiapkan alat dan bahan yang digunakan pada saat pelaksanaan praktikum, (2) tahap pelaksanaan praktikum selanjutnya yaitu pelaksanaan praktikum yang mengacu pada prosedur kerja yang terdapat pada setiap acara praktikum yang pada prosesnya setiap kelompok selalu didampingi oleh Coass, (3) tahap akhir/penutup yaitu terdiri dari respon akhir, pembuatan laporan praktikum,dan merapikan alat dan bahan yang sudah digunakan serta pengarahan untuk persiapan acara praktikum lanjutannya.

Terkait dengan relevansi antara materi perkuliahan dengan materi pada saat praktikum,sebagian besar responden menyatakan sangat relevan karena materi yang diajarkan di kelas sesuai dengan materi praktikum. Adapun alasan responden yang menyatakan kurang relevan disebabkan karena beberapa materi praktikum kurang sesuai dengan materi perkuliahan.Materi perkuliahan yang relevan dengan materi praktikum diantaranya; pembuatan larutan yang terdiri dari pembuatan satuan-satuan konsentarsi, asam-basa, pemurnian dan pemisahan senyawa atau campuran, uji karbohidrat, uji protein, dan uji lemak.Materi yang dianggap kurang relevan yaitu; analisis kimia pada produk rumah tangga, gas, dan reaksi redoks.

Selain itu, berkaitan dengan kemudahan dalam memahami materi praktikum dengan materi perkuliahan, hasil penelitian menunjukkan 
bahwa $80 \%$ responden menyatakan lebih mudah memahami materi perkuliahan karena penjelasan materi oleh dosen pengampu mata kuliah sangat detail tetapi materinya terlalu banyak sehingga membutuhkan waktu yang lebih dalam memahami materinya. Berdasarkan pernyataan responden $10 \%$ menyatakan lebih mudah memahami materi praktikum karena langsung dibuktikan antara teori dengan kenyataannya, dan 10\% menyatakan kedua-duanya karena antara materi praktikum dengan materi perkuliahan saling berkaitan.

Kesulitan yang dihadapi pada pelaksanaan praktikum Kimia Dasar, hasil penelitian menunjukkan bahwa 23,8\% responden menyatakan mengalami kesulitan, 21,4\% menyatakan tidak kesulitan, dan 54,76\% menyatakan kadang-kadang mengalami kesulitan dalam pelaksanaan praktikum Kimia Dasar. Adapun yang mengalami kesulitan disebabkan karena kurangnya bimbingan dari dosen pengampu mata kuliah, penjelasan coass kurang dipahami, tidak ada simulasi sebelumnya, kurang lengkapnya alat dan bahan, kesulitan dalam menyusun laporan praktikum, jadwal kuliah yang kurang sinkron dengan jadwal praktikum.

Sedangkan pernyataan responden yang menyatakan tidak mengalami kesulitan karena materi perkuliahan sangat berkaitan dengan materi praktikum, prosedur kerja yang sudah jelas dan sesuai dengan petunjuk praktikum, dan juga didukung oleh penjelasan Coass dan Laboran walaupun masih perlu ditingkatkan lagi.

Aspek lain yang menjadi fokus utama juga pada penelitian ini adalah kelayakan sarana dan prasarana yang terdapat di Laboratorium IPA Biologi FITK IAIN Mataram. Berdasarkan pernyataan responden menyatakan bahwa sebagain besar menyatakan kurang layak yaitu sebesar 59,52\%, dan menyatakan sudah layak sebesar 40,48\%. Laboratorium kimia / IPA harus dirancang dan dibangun dengan memenuhi kriteria baku yang 
mempertimbangkan unsur kesehatan, keamanan, peraturanperaturan yang bertujuan agar laboratorium dapat memberi manfaat secara optimal dengan mengeliminasi resiko secara minimal.

Alasan responden menyatakan kurang layak disebabkan karena ruang laboratorium masih kurang layak dan terlalu sempit untuk ukuran ideal suatu laboratorium, alat-alat praktikum masih sangat kurang sehingga sangat terbatas dalam melakukan kegiatan praktikum, demikian juga halnya dengan alat dan bahan yang dibutuhkan pada saat pelaksanaan praktikum juga masih sangat kurang. Sedangkan yang menyatakan layak berpendapat bahwa pelaksanaan praktikum dapat berjalan dengan lancer sehingga dijadikan patokan kelayakan dalam tersedianya sarana dan prasarana yang terdapat di Laboratorium Jurusan IPA Biologi IAIN Mataram.

\section{Upaya Yang Dilakukan Dalam Meningkatkan Kualitas Pelaksanaan Praktikum Kimia Dasar}

Kualitas pelaksanaan praktikum ditentukan oleh beberapa faktor yaitu; tersedianya alat dan bahan praktikum, kelengkapan sarana dan prasarana Laboratorium, pengelolaan laboratorium yang baik, partsipasi dosen, laboran, coass, praktikan, dan pengelola Lab. Untuk dapat melaksanakan praktikum dengan maksimal maka harus dilakukan upaya untuk meningkatkan kualitas pelaksanaan, perencanaan, dan evaluasi.

Berdasarkan hasil penelitian diperoleh data terkait upaya-upaya yang dilakukan dalam meningkatkan kualitas pelaksanaan praktikum kimia dasar diantaranya 59,52\% responden menyatakan setiap selesai praktikum selalu mencermati kelemahan-kelemahan pelaksanaan praktikum yang dilakukan, 26,2\% menyatakan kadangkadang melakukannya, dan $14,3 \%$ responden menyatakan tidak melakukan evaluasi terhadap pelaksanaan praktikum yang sudah dilakukan. 
Adapun kelemahan-kelemahan yang sering dialami oleh responden yaitu; kurangnya penguasaan materi praktikum, perbedaan pendapat antar coass, penjelasan yang kurang jelas dari coass, kurangnya koordinasi antara coass, format laporan yang berbeda-beda, kurangnya alat dan bahan, kurang kooperatif pelayanan coass terhadap praktikan, dan kurangnya partisipasi dosen pengampu mata kuliah.

Berdasarkan kelemahan-kelemahan tersebut maka upaya-upaya yang dilakukan untuk mengatasi permasalahan yang dialami antara lain; melakukan diskusi sebelum mulai praktikum, meningkatkan kerjasama antara dosen, praktikan, laboran, dan coass, meningkatkan koordinasi antar coass. Dari data yang diperoleh 83,35\% responden menyatakan selalu berupaya memperbaiki kelemahan-kelemahan pelaksanaan praktikum, 4,76\% menyatakan kadang-kadang, dan 11,9\% menyatakan tidak selalu melakukan perbaikan-perbaikan.

Upaya-upaya lainnya yang dilakukan untuk mengatasi kelemahankelemahan yang ada dengan cara mendiskusikan masalah-masalah yang dialami baik diskusi yang dilakukan dengan coass, laboran, dan dosen pengampu mata kuliah, dan data yang diperoleh menunjukkan bahwa $38,1 \%$ menyatakan melakukannya, 21,4\% menyatakan tidak, dan 40,5\% menyatakan kadang-kadang melakukan diskusi tersebut. Kurang optimalnya diskusi yang dilakukan disebabkan karena kesibukan dari coass dan dosen pengampu mata kuliah, kurang berani dengan dosen pengampu, dan keterbatasan waktu.

Selain itu, aspek utama dari aspek ini adalah untuk mengetahui pelaksanaan praktikum Kimia Dasar terlaksana dengan baik atau sebaliknya. Berdasarkan data diperoleh informasi bahwa 76,19\% responden menyatakan pelaksanaan praktikum Kimia dasar dilaksanakan dengan baik, dan 23,81 \% menyatakan kurang baik. Pelaksanaan praktikum Kimia Dasar dapat berjalan dengan baik 
karena diukur dari tercapainya tujuan pembelajaran dan prosedur kerja dapat dilaksanakan dengan tepat, dan coass, laboran, dan dosen pengampu mata kuliah telah menjalankan tugas dengan sebagaimana mestinya, sedangkan yang menjawab belum maksimal disebabkan karena kurangnya penjelasan dari coass, format laporan yang berbeda-beda,dan belum lengkapnya alat dan bahan praktikum yang dibutuhkan.

\section{Faktor-Faktor yang Mempengaruhi Kualitas Pelaksanaan Praktikum Kimia Dasar}

Dari penelitian yang dilakukan terkait dengan faktor -faktor yang mempengaruhi kualitas pelaksanaan praktikum Kimia Dasar dilihat dari beberapa aspek: motivasi mahasiswa, peran dosen, coass, dan laboran, serta ketersediaan sarana dan prasarana.Untuk aspek motivasi mahasiswa, berdasarkan data yang diperoleh 85\% responden menyatakan termotivasi dalam melaksanakan praktikum Kimia Dasar karena sebagai wahana untuk menambah pengetahuan, aplikasi teori dalam kehidupan, sebagian besar mahasiswa menyukai eksperimen, senang berinteraksi dengan bahan-bahan kimia yang berkaitan dengan kehidupan sehari-hari, sedangkan 15\% menyatakan kurang termotivasi dengan alasan cara pembimbingan coass yang kurang baik.

Menurut Mc. Donald (dalam Syaiful, 2002 ) Motivasi adalah suatu perubahan energi dalam diri seseorang yang ditandai dengan munculnya "feeling" dan di dahului dengan tanggapan terhadap adanya tujuan. Dari pengertian yang dikemukakan oleh Mc. Donald ini mengandung tiga elemen/ciri pokok dalam motivasi itu, yakni motivasi itu mengawalinya terjadinya perubahan energi, ditandai dengan adanya feeling, dan dirangsang karena adanya tujuan. ( Oemar hamalik, 1992 ) perubahan dalam diri seseorang itu terbentuk suatu aktivitas nyata berupa kegiatan fisik. Karena seseorang 
mempunyai tujuan tertentu dari aktivitasnya, maka seseorang mempunyai motivasi yang kuat untuk mencapainya dengan segala upaya yang dapat dia lakukan untuk mencapainya.

Peran Dosen, Laboran, dan Coass dalam pelaksanaan praktikum Kimia Dasar mendapat respon yang baik, dimana 23,81\% responden menyatakan sangat baik, 66,67\% menyatakan baik, 9,52\% menyatakan kurang baik, sedangkan untuk mengatasi kelemahankelemahan yang ada 60\% responden menyatakan selalu melakukan diskusi dan evaluasi yang dilakukan oleh dosen, laboran, dan coass, 30,95\% menyatakan kadang-kadang, dan 7,5\% responden menyatakan tidak melakukan diskusi disebabkan waktu yang terbatas sehingga dosen kurang memantau pelaksanaan praktikum.

Tersedianya Fasilitas (buku, alat, dan media) Pembelajaran di Laboratorium. Ketersediaan fasilitas di Lab berdasarkan hasil penelitian menunjukkan bahwa 40,47\% responden menyatakan tidak memadai, 59,53\% menyatakan sudah memadai. Adapun saran-saran yang dikemukan antara lain; bimbingan dosen pengampu lebih ditingkatkan lagi, praktikan lebih mempersiapkan diri lagi, coass harus lebih kooperatif, dan kelengkapan alat dan bahan masih sangat kurang.

\section{KESIMPULAN}

Berdasarkan penjelasan yang telah dideskripsikan di atas dapat disimpulkan bahwa;

1. Pada aspek persiapan pelaksanaan praktikum Kimia Dasar, secara umum subyek penelitian melakukan persiapan praktikum dengan cukup baik. Kelemahan mendasar yang terjadi pada fase ini adalah kurangnya pemahaman mahasiswa terhadap materi yang dipraktikumkan, mempersiapkan alat dan bahan, dan konsultasi dengan coass. 
2. Pada aspek pelaksanaan praktikum Kimia Dasar, dilakukan dalam 3 tahapan/proses yaitu, tahap persiapan, pelaksanaan, dan tahap akhir yang dalam pelaksanaannya berjalan dengan lancar. Adapun kelemahan dalam pelaksanaannya yaitu; kurang lengkapnya alat dan bahan, kesulitan dalam menyusun laporan praktikum, jadwal kuliah yang kurang sinkron dengan jadwal praktikum, kurangnya bimbingan dari dosen pengampu mata kuliah, penjelasan coass kurang dipahami.

3. Usaha yang dilakukan untuk meningkatkan kualitas pelaksanaan praktikum yaitu dengan peningkatan kualitas coass, evaluasi rutin sebelum dan sesudah praktikum, dan meningkatkan koordinasi dengan antara laboran, coass, dosen pengampu dan pihak jurusan.

4. Sedangkan berkaitan dengan faktor yang mempengaruhi kualitas pelaksanaan praktikum Kimia Dasar menunjukkan bahwa motivasi mahasiswa mengikuti praktikum sangat tinggi, peran dosen, coass, dan laboran masih perlu ditingkatkan, serta ketersediaan sarana dan prasarana yang masih terbatas.

\section{DAFTAR PUSTAKA}

Amien Moh., 1987. Mengajarkan Ilmu Pengetahuan Alam (IPA) Dengan menggunakan Metode "Discovery" dan "Inquary" Bagian I. Jakarta: Departemen Pendidikan dan Kebudayaan Dirjen .Dikti. P2LPTK.

Dahar Ratna Wilis, 1989. Teori-Teori Belajar.Jakarta : Erlangga

Depdikbud (1979) Pengelolaan Laboratorium Sekolah dan Manual Alat IPA. Jakarta : Direktorat Pendidikan Menengah Umum.

Depdiknas, 2004. Pedoman khusus pengembangan silabus berbasis kompetensi SMP mata pelajaran Pengetahuan Alam. Jakarta: Depdiknas.

Fraenkel, Jack dan Wallen, Norman. 2003. How to Design and Evaluate Research in Education. New York. McGraw Hill Companies. 
Hendro Darmodjo dan Jenny R.E. Kaligis, 1993. Pendidikan IPA 2. Jakarta : Depdik bud. Dirjen.Dikti.Proyek Pembinaan Tenaga kependidikan.

Hall, F.J. (1986). Experimental Chemistry.Massachusetts : D.C. Heath and Company.

Isaacs, S. \& Michael, W.B., 1984. Handbook of research and evaluation. San Diego, California: edit Publisher

Junior Secondary education, 2004.Science Bilingual. Jakarta: Depdiknas

John W. Hansen \& Gerald G. Lovedahl. (2004). Developing Technology Teachers : Questio-ning the Industrial Tool Use Model. Journal of Technology Education. 15 (2), 20 - 32.

Maryana, 2007.Evaluasi Kegiatan Praktikum IPA di SMP N Kabupaten Bantul.Naskah tesis.Universitas Negeri Yogyakarta.

Mel Silberman. (2002). Active Learning : 101 Strategies to Teach any Subject (Terjemahan Sarjuli, Adzfar Ammar, Sutrisno, et. Al.). Boston : Allyn and Bacon. (buku asli diterbitkan tahun 1996).

Moh. Amien. (1997). Buku Pedoman Laboratorium dan Petunjuk Praktikum Pendidikan IPA Umum (General Science) untuk LPTK. Jakarta : Depdikbud.

Miles dan Huberman, 1992.Analisis Data Kualitatif.Diterjemahkan oleh Tjetjep Rohendi Rohidi. Jakarta. UI Press.

Moleong, Lexy. 2006. Metodologi Penelitian Kualitatif. Bandung. PT. Remaja Rosdakarya.

Ratna Wilis Dahar. (1986). Pengelolaan Pengajaran Kimia. Jakarta : Karunika.

Santyasa I Wayan, M.Si, 1997.Efektifitas Penterapan Modul dan Metode Demonstrasi Terhadap Perubahan Miskonsepsi dan Hasil Belajar Mahasiswa Jurusan P.MIPA. STKIP Singaraja : Laporan Penelitian. 
Sitti Faika dan Sumiati Side.2010. Analisis Kesulitan Mahasiswa dalam Perkuliahan dan Praktikum Kimia dasar di Jurusan Kimia FMIPA Universitas Negeri Makasar.UNM.Skripsi.

Subiyanto. (1998). Pendidikan Ilmu Pengetahuan Alam. Jakarta : Depdikbud.

Sudaryanto, Indrawati, dan Endang Kowara. (1998). Pengelolaan laboratorium IPA dan Instalasi Listrik. Jakarta : Depdikbud.

Sudiana I Ketut, Suardana I Nyoman, Selamat Nyoman, 1995.Penyelenggaraan Kuliah Pra -Laboratorium untuk menunjang pelaksanaan Praktikum Kimia pada mahasiswa tahun Pertama Bersama (TPB) Jurusan Pendidikan MIPA STKIP Singaraja Tahun 1995/1996.STKIP Singaraja LaporanPenelitian.

Sugiyono. 2006. Metode Penelitian Kuantitatif, Kualitatif, dan R \& D. Bandung. Alfabeta.

Sinnadurai W. et.al, 2007.Anomali Sains dalam pengajaran dan pembelajaran sains teras di kalangan pelajar tingkatan empat.www.ga.unc.edu

Sumaji, 2003.Pendidikan sains yang humanistis. Yogyakarta: Kanisius

Terry, R.G. (1977). Principles of Management.Seventh Edition.Illionis : Ricard D. Irwin Inc.Homewood

The General Safety Committee. (1954). Guide for Safety in the Chemical Laboratory. New York : D. Van Nostrand Company. Inc. 